
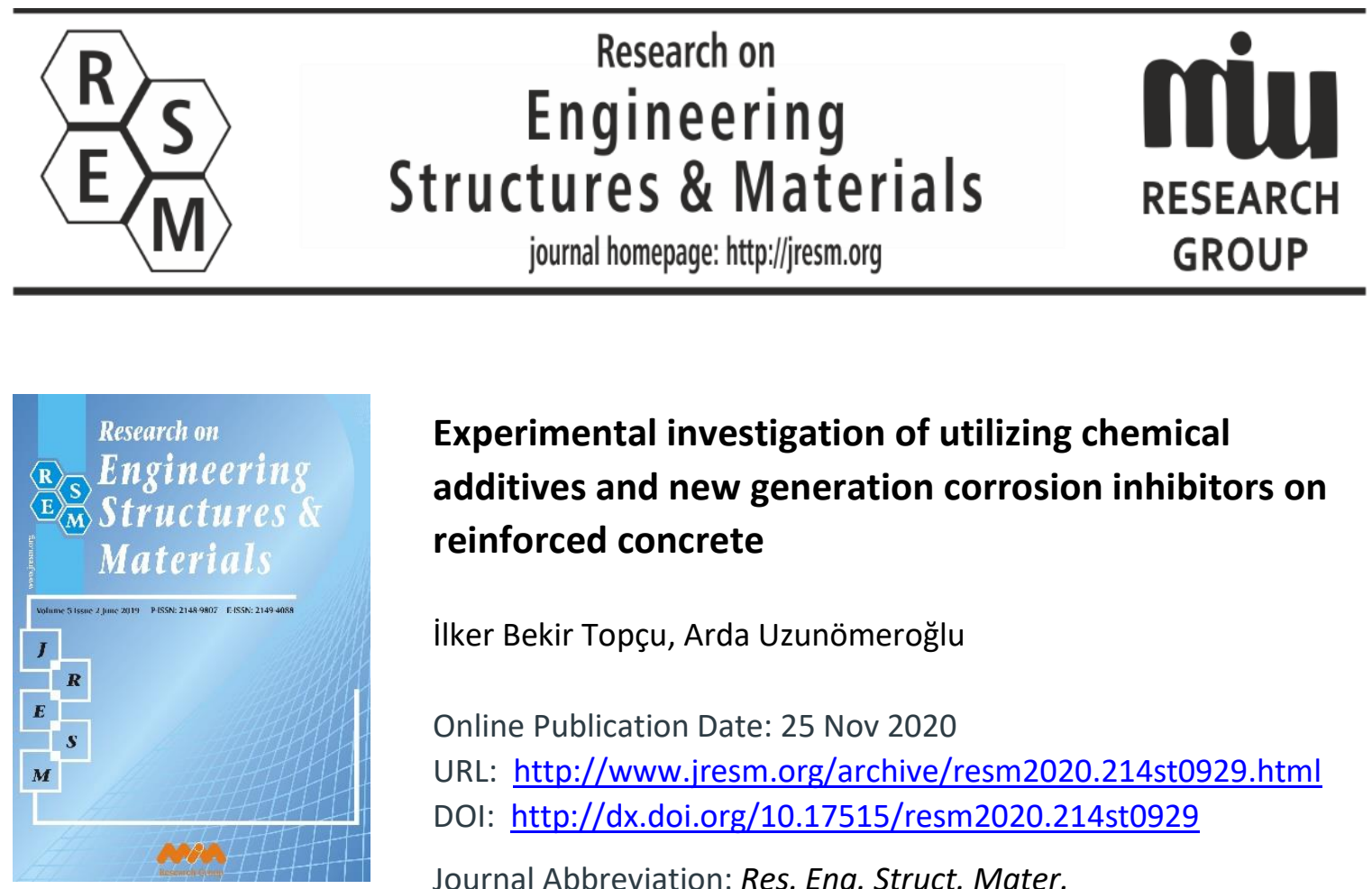

\title{
Experimental investigation of utilizing chemical additives and new generation corrosion inhibitors on reinforced concrete
}

ilker Bekir Topçu, Arda Uzunömeroğlu

Online Publication Date: 25 Nov 2020

URL: http://www.jresm.org/archive/resm2020.214st0929.html

DOI: http://dx.doi.org/10.17515/resm2020.214st0929

Journal Abbreviation: Res. Eng. Struct. Mater.

\section{To cite this article}

Topcu B T, Uzunomeroglu A. Experimental investigation of utilizing chemical additives and new generation corrosion inhibitors on reinforced concrete. Res. Eng. Struct. Mater., 2021; $7(1): 13-34$.

\section{Disclaimer}

All the opinions and statements expressed in the papers are on the responsibility of author(s) and are not to be regarded as those of the journal of Research on Engineering Structures and Materials (RESM) organization or related parties. The publishers make no warranty, explicit or implied, or make any representation with respect to the contents of any article will be complete or accurate or up to date. The accuracy of any instructions, equations, or other information should be independently verified. The publisher and related parties shall not be liable for any loss, actions, claims, proceedings, demand or costs or damages whatsoever or howsoever caused arising directly or indirectly in connection with use of the information given in the journal or related means.

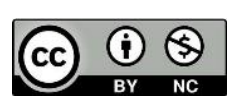

Published articles are freely available to users under the terms of Creative Commons Attribution - NonCommercial 4.0 International Public License, as currently displayed at here (the "CC BY - NC"). 


\title{
Research on Engineering Structures \& Materials \\ journal homepage: http://jresm.org
}

Research Article

\section{Experimental investigation of utilizing chemical additives and new generation corrosion inhibitors on reinforced concrete}

\author{
İlker Bekir Topçu*a, Arda Uzunömeroğlu ${ }^{\text {b }}$ \\ Department of Civil Engineering, Eskişehir Osmangazi University, Eskişehir, Turkey.

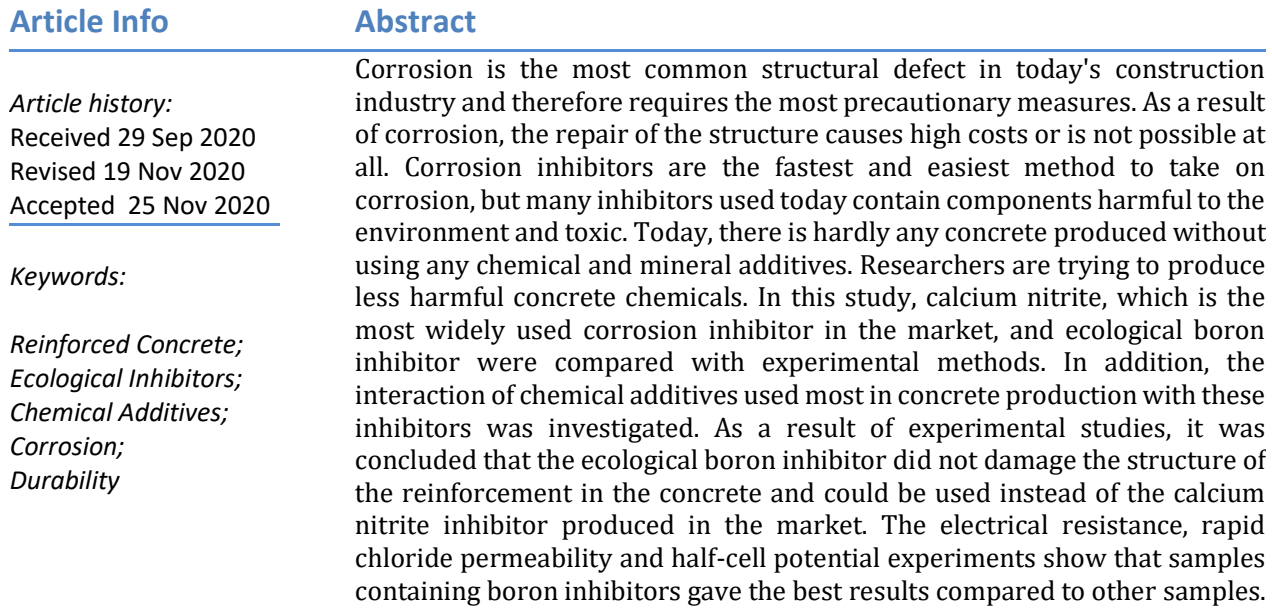

(C) 2021 MIM Research Group. All rights reserved.

\section{Introduction}

The cost of the material damage by corrosion amounts to millions annually moreover human life and suffering cannot be assessed. In many ways, the term corrosion protection is too narrow to describe the activities of structural scientists dealing with corrosion problems. Therefore, the cost of corrosion can be a higher magnitude than expected.

Rebars are integral component of reinforced concrete structures. High permeable concrete can allow the entrance harmful component that causing corrosion but corrosion is negligible when concrete and rebar are good contact with each other. This is so even when calcium chloride has been used to accelerate the hardening of the concrete [1].

The customary criterion of concrete quality is compressive strength but for the protection of reinforcement and it is more important than the concrete should be sufficiently fluent (lowslump) to envelop the rebar. Even if this involves using more cement than would be necessary merely to provide a given strength. In the concrete mix, high strength is desirable because more durable concrete can prevent the crashing in the concrete surface due to corrosion.

Corrosion causes expansion of steel reinforcement developing high-tensile stresses in the order of $20 \mathrm{MPa}$ to $30 \mathrm{MPa}$ in the surrounding concrete. These stresses are much higher than the tensile strength of concrete, and so cracks are developed in concrete in the vicinity of steel, resulting in the deterioration of reinforced concrete structures. Many countries are faced with

*Corresponding author: ardauzunomeroglu@gmail.com

a orcid.org/0000-0002-2075-6361; b orcid.org/0000-0003-4204-0564;

DOI: $\underline{\text { http://dx.doi.org/10.17515/resm2020.214st0929 }}$

Res. Eng. Struct. Mat. Vol. 7 Iss. 1 (2021) 13-34 
the threat of corrosion, according to researchers. Corrosion is not only the loss of the building but also a formation that endangers human life, social order and economy. In any corroded structures, even the repair of partially-damaged sections involve huge expenditure [2].

In this study separately from the others, it was investigated that interaction of calcium nitrite inhibitor (most widely used corrosion inhibitor in the market) and other chemical additives, also the effect of new generation ecological boron inhibitor (natural corrosion inhibitor) to the reinforcement, in terms of concrete durability and corrosion process were compared with experimental methods.

\section{Literature Review}

\subsection{Electrochemical Corrosion}

In electrochemical corrosion, all the processes of metal corrosion in the solution of electrolytes showing electrolytic properties such as in the soil and concrete (which can be considered an imperfect electrolyte) or by exposure to the atmosphere. On the other hand, the corrosion of metal at room temperature can normally take place with high velocity only in the presence of moisture; on the other hand, in a dry medium, the attack is very small or non-existent [3].

During the hydration of cement with water, a protective layer is formed in the presence of free lime around the reinforcing bar in concrete. The $\mathrm{pH}$ of this layer is about 13. During the service life of the structure, the $\mathrm{pH}$ value of this layer is reduced due to the chemical reaction caused by the ingress of moisture, oxygen, chlorides, sulfates and other chemicals present in the environment. During the initial stage of corrosion, rebar becomes the anode of the corrosion cell in which the metal is oxidized to form ferrous ions. The corresponding reaction at the cathode is the reduction of oxygen to produce hydroxyl ions so that the initial corrosion product can be considered to be represented by ferric hydroxide. This rust is a hydroxide of $\mathrm{Fe}_{2} \mathrm{O}_{3}$ (ferric oxide) and it precipitates as yellow residue in cavities around the anode. The resulting reactions are given below:

$$
\begin{aligned}
& \mathrm{Fe}^{+2}+2 \mathrm{OH}^{-} \longrightarrow \mathrm{Fe}(\mathrm{OH})_{2} \\
& 4 \mathrm{Fe}(\mathrm{OH})_{2}+\mathrm{O}_{2}+2 \mathrm{H}_{2} \mathrm{O} \longrightarrow 4 \mathrm{Fe}(\mathrm{OH})_{3} \\
& \left.2 \mathrm{Fe}(\mathrm{OH})_{3} \longrightarrow \mathrm{Fe}_{2} \mathrm{O}_{3}+3 \mathrm{H}_{2} \mathrm{O}\right\} \text { Hydrated Ferric Oxide (Rust) }
\end{aligned}
$$

Corrosion in an aqueous medium can be considered as an oxidation-reduction that concerns the metal and which takes place at the metal/solution interface causing the transfer of electrons through the metal and ions through the solution. As oxidation, we mean any phenomenon which causes the removal of electrons from the metal. In such cases, there will be corresponding reduction reactions with the surrounding medium. Therefore, the process takes place by an electro-chemical mechanism so that the metal from the metallic state goes into the solution as hydrated cations through anodic dissolution, or it is changed into a solid compound through anodic oxidation. The anodic process always takes place together with an equivalent cathodic reduction of some constituent in the aqueous electrolyte [4]. 


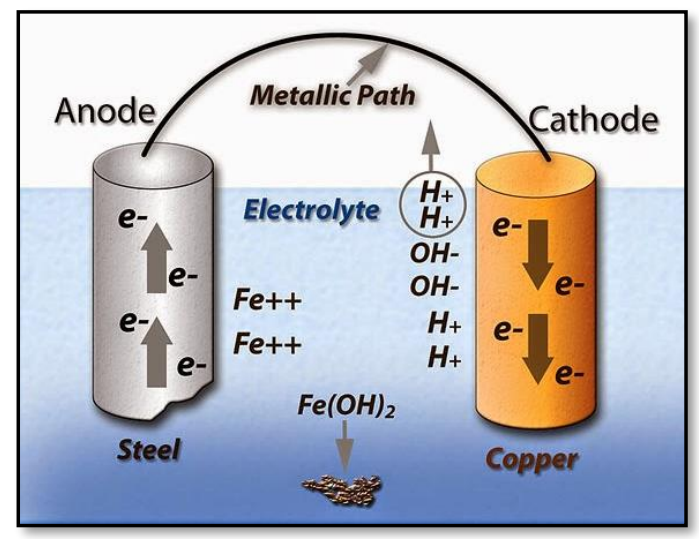

Fig. 1 Basic corrosion cell [5]

As the electrons are formed in the anodic region and are fixed in the cathodic region, a continuous movement of electrons must take place through the metal, and at the same time a movement of anions and cations into the solution. Electron flow is from the anode to the cathode, and the electrons continuously leave the anode and reach the cathode (Fig. 1). As this process continues, the separated electrons damage the anode (reinforcement) over time and consume it (corrosion). In other words, the corrosion process in solution implies:

- Passage of electrons into solution (electrolyte)

- Passage of electrons from the metal (rebar) to an acceptor cathode in the solution

- An ionic current in the solution

- An electronic current on the metal.

The corrosion rate will be controlled by the slowest process in the whole chain. From the definition of electrochemical reactions given below, we can assume that we can find at the corrosion potential a fixed value of corrosion rate. The corrosion rate is electrolytically equivalent to the current rate between the anodes and cathodes of the corrosion cells (Fig. 2).

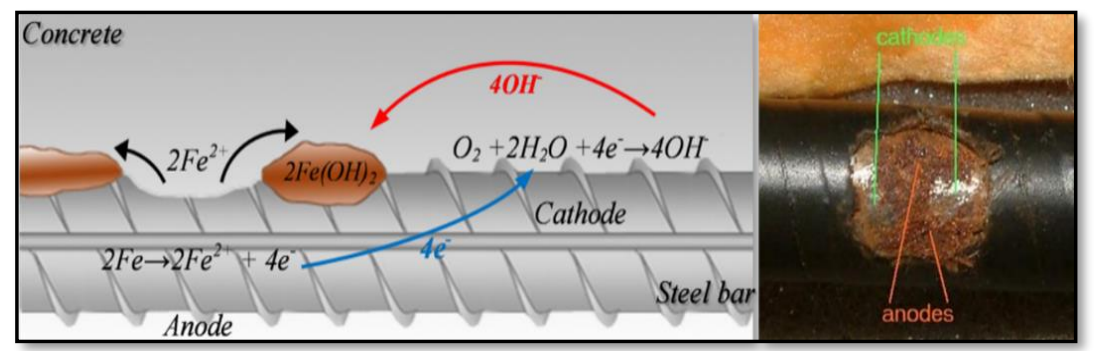

Fig. 2 Electrochemical reaction on rebar [6]

The passage of positive charge from the metal to the medium (at the anode) is always equal to the passage of negative charges from the metal to the medium (at the cathode). This is quite valid, either if cathodes and anodes are made by metals of different characteristics in contact in the medium, or if on the surface of the same metal the anodic or cathodic process takes place at atomic distances. The hardened zones of the metal normally have potential values less noble than the unhardened ones, and consequently, show a greater tendency to dissolve. In the case 
of alloys have more than one phase, the different nature of the phases is promoting the formations of local cells $[7,8]$.

\subsection{Effect of Environmental Conditions}

Water and oxygen are mainly responsible for corrosion initiation. Their presence in concrete depends upon the quality, thickness of the concrete cover around the steel, the temperature, the humidity and the chemical contents in the surrounding environment [9]. Generally, hot and humid climatic environment are major factors responsible for the corrosion of reinforcement in the world. The designers and engineers must seek to change the environment, separate the metal from the environment, or reduce the corrosion reactions.

\subsubsection{Moisture}

The rate of the electrochemical reaction in a corrosion cell depends upon the moisture content in the vicinity of reinforcement in concrete. The moisture can enter the concrete in several ways, such as; high water/cement ratio, by the concrete surface (outside or inside) or concrete ingredients. Increasing the water ratio of concrete in order to make more workable concrete is very dangerous. Because, when water evaporates and exits, the remaining concrete becomes more permeable. Therefore, the water-cement ratio and the impermeability of concrete play an important role in the corrosion process in concrete structures. From durability consideration, the water-cement ratio is limited in reinforced concrete structures. Similarly, moisture absorption is limited to $5 \%$ to $10 \%$ depending upon the type of concrete, the importance of the structure and the exposure conditions [10].

\subsubsection{Chlorides}

The chloride ions are accelerated anode and cathode reaction in the corrosion process. These ions are very easily and rapidly penetrating the deeply of concrete. Chloride ions are depassivated the passive steel and reinforced concrete become more vulnerable against corrosive attacks. They also increase the electrical conductivity of concrete and accelerate the rate of corrosion. Chloride also affects the long-term strength development of concrete and impermeability. Chloride ions at the steel surface cause loss of passivity that provided by the normal alkali protection of free lime. They also reduce the resistivity of concrete. When chloride ions exceed the critical value, rebar is depassivated easily. Corrosion can occur where the chloride content is higher than the critical value [11].

Presence of chloride ions in concrete depends some variable (concrete cover, cement type, condition etc.). It is claimed that the presence of $2-7 \%$ calcium chloride does not increase to corrosion of steel when lime water has been used instead of plain water for mixing concrete. However, similar concrete made with plain water in the $2 \%$ calcium chloride environment, can cause corrosion. It is similarly claimed that sodium silicate prevents corrosion when calcium chloride is presented in reinforced concrete [12].

\subsubsection{Oxygen}

The oxygen is existing in concrete in different concentrations and it causes different potentials that consist anode and cathode poles. The corrosion which is quantitatively measured in grams of steel per year depends upon the oxygen flow rate to the reinforcement through the concrete cover [13]. The oxygen flow rate to the rebar depends upon the cover thickness, water-cement ratio and humidity. The oxygen flow rate drops considerably with increasing cover thickness and humidity. The minimum cover thickness for different exposure conditions varies from 13 to $75 \mathrm{~mm}[14]$.

\subsection{Effect of Corrosion on Structures}

Reinforced concrete steels are expected to serve for many years without being corroded. However, with the increase of permeability, high alkali level begins to decrease, with the loss of 
alkali passivation, it becomes unable to protect the concrete reinforcement and corrosion formation begins. Corrosion causes volume increase and creates cracks parallel to the reinforcement [15]. Once the concrete cracks, it is completely vulnerable to atmospheric effects, and the structure quickly completes its service life (Fig. 3). Corrosion is not only a visual defect but also a chemical reaction that adversely affects the durability of the concrete.
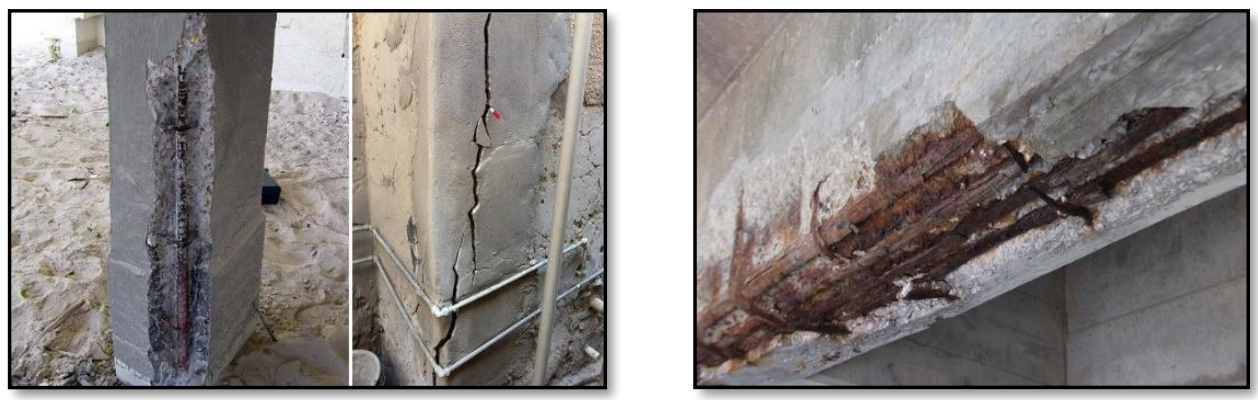

Fig. 3 Damages caused by reinforcement corrosion in columns and beams [16]

Reinforcement embedded in concrete expands due to corrosion and cracks develop when the stresses caused by the expansion exceed the tensile strength of the concrete. An expands of about $0.1 \mathrm{~mm}$ to $0.2 \mathrm{~mm}$ would be sufficient to produce cracks and to damage the concrete cover [17]. These processes depend upon the interaction of the following effects: Chloride content, moisture ratio, loss of resistivity of the concrete, oxygen diffusion, cover thickness, tensile strength, the ratio of cover thickness to rebar diameter, the spacing of the rebars.

\subsection{Prevention of Corrosion}

Depending upon the stage of corrosion, the cost of repairing the corroded concrete structure is much higher than the initial cost incurred for additional measures taken during construction to prevent corrosion. Therefore, it is a more economical and rational way to take the necessary precautions before the structural member getting corrodes.

\subsubsection{Cement}

The type of cement used plays a significant part in chloride and sulfate diffusivity in the hardened cement matrix. The risk of corrosion attack decreases, as the thickness of the concrete cover and the ratio of cement to aggregate is increased. The protection provided by Portland and slag cement is good, the environment provided by the slag-cement concrete being less alkaline but more stable. Pozzolan with silica fume reacts with the free lime and form calcium silicate. With this reaction impermeability, density, and strength of the concrete are increasing dramatically.

\subsubsection{Aggregates and Water}

Aggregates should be washed thoroughly to remove fine dust, silt, clay and sea-salts. Tests for any chloride or sulfate content and for soundness should be conducted on representative samples. The chlorides should not be more than $0.06 \%$ in the sand and $0.03 \%$ in coarse aggregates. Sulfates in aggregates, ( $\left(\right.$ uch as $\mathrm{SO}_{3}$ ) should not exceed $0.4 \%$. The $\mathrm{pH}$ value of water should be more than 6 . The chloride and sulfate contents should not exceed $500 \mathrm{ppm}(0.05 \%)$ and $1000 \mathrm{ppm}(0.10 \%)$ respectively [18].

\subsubsection{Concrete Design}

For the construction of the concrete structure is always desirable to design low-slump concrete. The mix should be free from segregation and bleeding. Concrete should conform to the followings in order to prevent corrosion: 
- The amount of cement in the concrete mix must higher than $350 \mathrm{~kg} / \mathrm{m}^{3}$

- Water-cement ratio should not be more than 0,50. The water-cement ratio should be as low as possible, because less use of water makes concrete more impermeable.

Commercially-available superplasticizers can be used in quantities appropriate to the mix design so as to increase workability, strength and durability. Corrosion inhibiting mixtures such as calcium nitrate at the rate of $20 \mathrm{lt} / \mathrm{m}^{3}$ of concrete may be used to prevent corrosion [19]. It has been determined by the researcher that inadequate utilization of corrosion inhibitors is increases corrosion. In this research, calcium nitrates and ecological (green) inhibitors are compared in order to find the differences between these two additives.

\subsubsection{Reinforcement}

In reinforced concrete, the use of high-strength deformed rebars with enough spacing is a simple and common way. While doing this, congestion between the reinforcement at any section of the structural member should be avoided.

Nowadays, it is quite common to protect reinforcing bars by galvanizing, especially for use in concrete which is to be exposed in an aggressive atmosphere. In practice, zinc coating is generally done by the hot-dip method. In this method, a thin zinc alloy layer is formed on the rebar surface. There are several advantages that can be gained when using galvanized reinforcing bars. Reinforced concrete can be completely isolated from its surroundings by coating with zinc [20]. However, this is an expensive operation and is rarely carried out properly, and if the cover is insufficient or the concrete mix is of poor quality, it can lead to spalling of the concrete. Some researchers reported that galvanized reinforcement does not resist corrosion long enough to justify the additional cost. Galvanized rebars corrode very rapidly if they are brought into contact with electrochemically passive materials (noble metals such as stainless steel, copper, brass, etc.) so their use is not recommended.

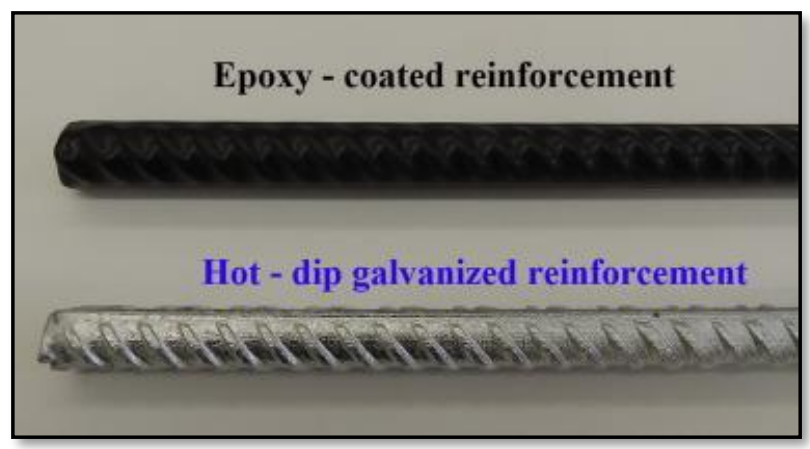

Fig. 4 Epoxy coated and galvanized reinforcements [21]

The adherence of steel and concrete is usually good but it may be weakened by thermal expansion. If extra protection of steel is considered essential, paints have can be used but they are rarely long-lived. Epoxy coatings protect the reinforcement from calcium chloride attack, but some paints of this type cause a lack of bond strength between the steel and the concrete. Reinforcement with epoxy coating has been used for many years in corrosive environments.

Epoxy is a two-component resin. This chemical can be applied to reinforcement by spraying or dipping (Fig. 4). It hardens in a short time after application and adheres well to concrete, steel and wood. Such bars are comparatively more expensive than conventional reinforcement. It is effective in increasing corrosion resistance and is recommended for use in structures with high corrosion risk. Epoxy coatings are also long-lasting and can be used in underwater work. 
Bouazaoui et al [22] studied the interfacial shear strength between the steel bar surface and the concrete surface of steel rods that were previously bonded with epoxy resin into concrete using confined pullout test. The yield strength of the steel bar obtained through the test, was $340 \mathrm{MPa}$ and the concrete had an average compressive strength of $40 \mathrm{MPa}$ at 28 days. While the test continues, the load is gradually increased until the failure occurred in the steel-concrete interface. The author verified that the epoxy coatings significantly improved the shear and tensile stress distribution along with the interface between the steel surface and the concrete surface.

Stainless steel bars are about four times more costly than conventional reinforcement. These steels may be used for exceptional structures that highly require non-magnetic and corrosionresistant reinforcement [23].

\subsubsection{Compaction and Curing}

The concrete in the mould should be compacted thoroughly to eliminate honeycombs and voids (Fig. 5). Enough care should be exercised during vibration to ensure that the reinforcement is embedded with a proper bond [24]. Too much vibration leads to bleeding and segregation. Late vibration can be done to eliminate bleed-water film and fissures, if any, under the steel and the coarse aggregate.

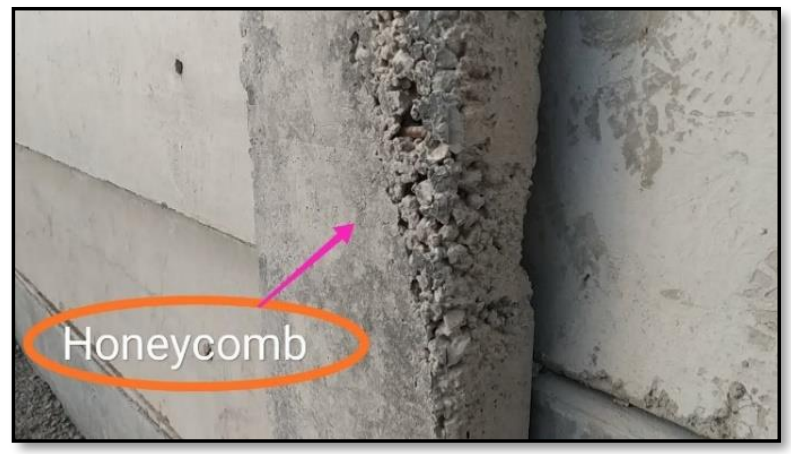

Fig. 5 Insufficient implementation of vibration on concrete pouring [25]

The water used for mixing the constituents of the concrete should be a sufficient amount. The exposed area of the concrete to the outside should be protected from drying during the pouring. Because there is a possibility of concrete rapid drying due to the high temperatures. Therefore, concrete must be water cured within about 15 minutes after final finishing to avoid plastic shrinkage cracks. Curing should be continued for seven days so that the concrete attains a strength equal to $70 \%$ of its design strength [26]. To keep concrete wet continuously during the curing period; pigments, heavy-duty curing compounds, plastic sheets, waterproof papers and other wet materials may be used.

\subsubsection{Concrete Cover}

The quality of the concrete and the thickness of the concrete cover is the most important factors to protect the reinforcement from corrosion. Permeability and cracking of the concrete cover will allow easy penetration of aggressive agents such as atmospheric gases, chlorides, sulfates and carbon dioxide. Therefore, where the climate is highly aggressive with a severe atmosphere containing chlorides and other salts, the impermeability and thickness of the concrete cover must be increased (Fig. 6). 


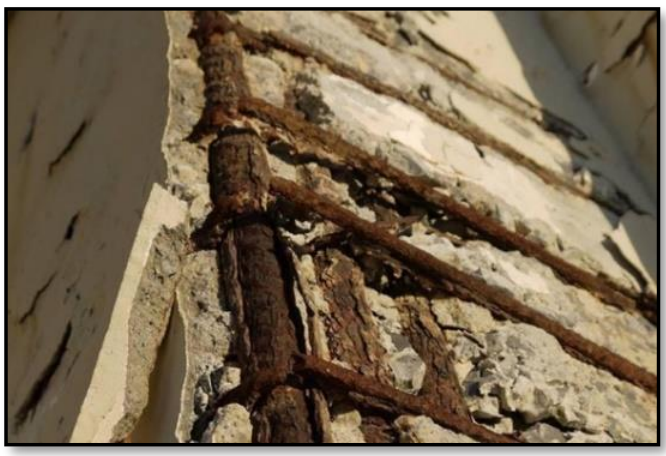

Fig. 6 Inadequate use of concrete cover [27]

Depending upon the type of the structural component and exposure conditions, sufficient and recommended thickness of the concrete cover is between 15 to 70 millimeters [28]. Structures are physically inspected to assess corrosion damage. They may be heavily corroded or maybe in the initial stages of corrosion. When the visual inspection shows cracking and spalling with corrosion of steel all along with the member, the member is replaced with a new component.

In some cases, concrete structures can expose intense corrosive effects, the delamination of surface cracks may occur. In such cases, the member is repaired by materials as follows:

- Remove the loose concrete from the surface;

- Rebar should clean from the rust;

- Coating the reinforcement bar with epoxy paint;

- Addition of steel to substitute the loss of reinforcement if necessary;

- Jacketing the surface with cement-based material (Fig. 7);

- Surface of concrete should be coated;

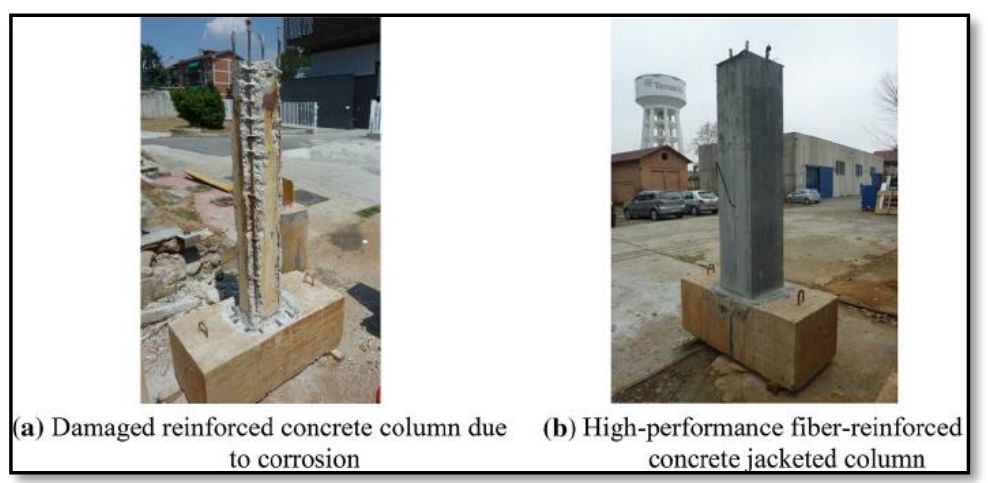

Fig. 7 Retrofitting the corroded reinforced concrete columns with jacketing [29]

In the figure, repairing and strengthening of the concrete cover of reinforced column is shown. Habib et al. repaired the corrosion damage in the reinforced concrete column with the jacketing using fiber reinforcement. With this process reinforced concrete columns can be improved against earthquake [30]. 


\subsection{Corrosion Inhibitors}

During the working, the structural metals are actually the most critical materials which can suffer from corrosion; a real danger as a result of corrosion to the structures can follow. Protective measures one of which consists of the use of chemical compounds that added in small concentrations to the aggressive environment are able of reducing corrosion of the metal exposed to it. The reaction tendency of the metal is decreased by diminishing the aggressivity of the environment.

Usually, corrosion inhibitors are able to prevent general corrosion, but their action is more difficult against localized corrosion processes. The form of attack represents the greater destruction of material based on the weight of lost metal. However, from the technical points of view, the uniform attack is not the most important, because the life of the metal can be foreseen and the attack can be easily prevented by using corrosion inhibitors [31].

By using corrosion inhibitors, we try to avoid or reduce the corrosion of metallic materials with the addition of chemicals (usually at a low concentration) to corrosive medium. The inhibitors used in structural systems must satisfy the following criteria:

- The cost of a sufficient quantity of inhibitor, and such analytical work as if necessary, must be economic.

- The troubles which may arise should the inhibitor concentration fall, and the likelihood of such a fall should be considered.

- Some inhibitors (cathodic inhibitors) are slowly precipitated either, by decomposition or by reaction with a minor constituent.

- The corrosion inhibitors are toxic liquids that may present a problem in the disposal.

- All the materials should be protected from the threat of corrosion or at least not increasing it [32].

Corrosion inhibitors are chemicals that are harmful to the environment and people. Although they are added to concrete in small amounts, they infiltrate the soil during the perspiration of the concrete and cause environmental pollution. They have lethal effects on animals and carcinogenic effects on humans. The most used and commercial corrosion inhibitor is calcium nitrite. The inhibitor, which is added to the concrete like water during mixing, forms a passive film layer around the reinforcement and protects the reinforcement from corrosion.

Against these toxic effects of corrosion inhibitors, researchers have sought a more ecological inhibitor. As a result of the studies carried out on the boron mine, it has been discovered that some compounds synthesized from this mine protect the metal from corrosion. Turkey has about $74 \%$ of the world's boron reserves, so researchers are increasing their work on boron [33]. As a result of our investigation, it was seen that boron inhibitor shows a mixed type inhibitor specification, can't harm nature and people, and it has increased the corrosion resistance of concrete more than other inhibitors (Fig. 8). Boron inhibitor takes its ecological feature from the borane complex it contains and does not contain any other chemicals. However, the exact content cannot be shared. The biggest advantage of this inhibitor is to be used boron reserves are abundant in Turkey.

Gerengi et al. compared the results of boron cation ionic liquids EMITFB (1-ethyl-3methylimidazolium tetrafluoroborate) inhibitory activity in $0.1 \mathrm{M} \mathrm{HCI}$ environment with using Electrochemical Impedance Spectroscopy (EIS) and Potentiometric Polarization (TP) methods (This inhibitor is the new generation ecological boron inhibitor and was used in this current study). They have seen that metal surface is disrupted by the action of $\mathrm{HCl}$ when St37 metal is exposed to a $0.1 \mathrm{M} \mathrm{HCl}$ environment. When the inhibitors are added to the working environment, they observed that the film is formed on the metal surface and the formed film protects the metal against corrosion [34]. 

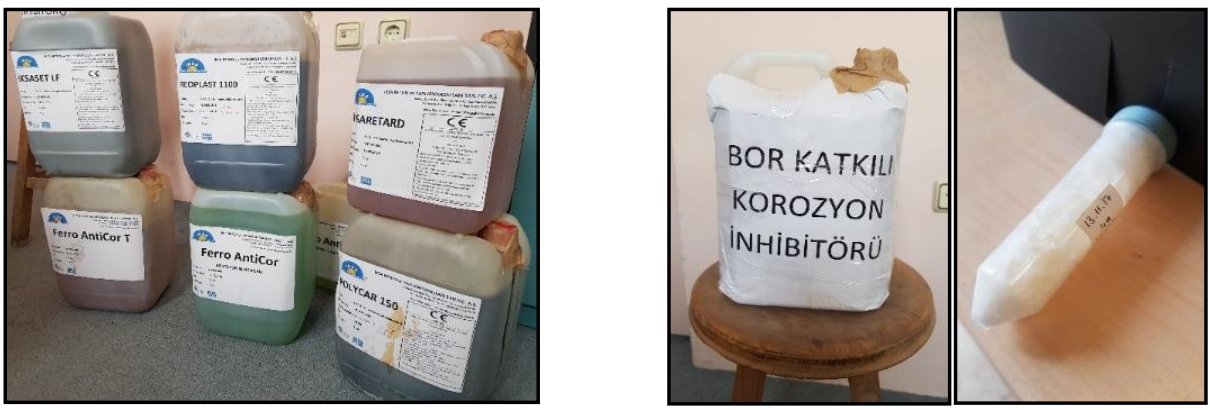

Fig. 8 Chemical additives and ecological boron corrosion inhibitor used in this study

Abdulrahman et al. [35] studied the design for a long-life span quality concrete. The main advantage of using calcium nitrite is inhibiting the corrosion process caused by both chloride ions by carbonation and the action of sulfate ions. Depends on the quality of the concrete, nitrates increase the strength gain rate according to the exposure conditions, and the amount of calcium nitrite. Among the side effect of concrete, nitrites accelerate the setting of fresh concrete.

Ryu et al. [36] investigated that use of calcium nitrite-based inhibitors needs greater care in estimating the quantity. Because, when the amount of inhibitor is not sufficient, it will increase the corrosion and damage rapidly the structural member. Thus, it is of utmost importance to define the optimal amount to be added for the inhibitor to work properly.

Okeyini et al. [37], as a result of their physico-chemical analysis on the Phyllanthus muellerianus plant, it was understood that P.muellerianus has non-toxic, environmentally friendly potentials and protects metal from corrosion. As a result of the researches, they concluded that the components obtained from the leaf of P.muellerianus, when used as additives in reinforced concrete samples immersed in a $0.5 \mathrm{M} \mathrm{H}_{2} \mathrm{SO}_{4}$ environment, reduce the total corrosion of reinforcement in reinforced concrete. As the P. Muellerianus concentration used in the test samples increases, the total amount of corrosion decreases.

\section{Present Experimental Work}

Today, there is hardly any concrete produced without using any chemical and mineral additives. In our study, optimal concentration value of inhibitors was determined as $20 \mathrm{lt} / \mathrm{m}^{3}$ and this amount kept the concentration of calcium nitrite insufficient amount. In addition, other chemical additives were used at an optimum rate (approximately 2\%) in accordance with the standards. The preparation of reinforced and unreinforced samples is shown in Figure 9. 


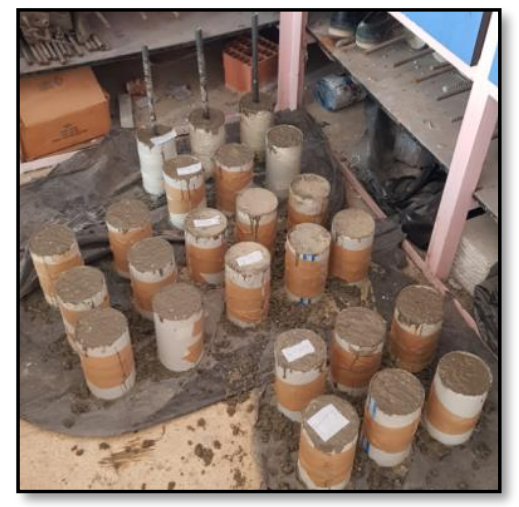

Fig. 9 Preparation of reinforced and unreinforced samples

\section{Materials and Methods}

\subsection{Materials}

Concrete samples were prepared with cement, water, aggregate and sand. In this research, CEM I 42.5 R cement was utilized conforming to the TS EN 197-1 [38]. The physical and chemical properties of Type I Portland cement are presented in Table 1. The aggregates are obtained from local sources and the maximum size of coarse aggregate was $12.5 \mathrm{~mm}$ and limestone crushed sand was $1.25-5 \mathrm{~mm}$. The reinforced concrete samples were prepared with a 0.50 water-cement ratio and a dosage of cement in the mixture of $350 \mathrm{~kg} / \mathrm{m}^{3}$. In this research, 16 $\mathrm{mm}$ diameter $\mathrm{S} 420$ deformed reinforcement steel was used. As a result of the experiments, the yield strength of the steel was $479 \mathrm{MPa}$ and the tensile strength was $602 \mathrm{MPa}$. These values provide the limits specified in TS 708 [39].

Table 1. Physical and mechanical properties of portland cement

\begin{tabular}{ccc}
\hline & Chemical Composition (\%) & CEM I 42.5 R \\
\hline & Specific Weight & 3.11 \\
& Blaine Surface (cm $/ \mathrm{gr})$ & 3501 \\
Physical & Residue on Sieve - 0.090mm (\%) & 0.31 \\
Properties & Residue on Sieve - 0.045mm (\%) & 5.11 \\
& Standard Consistency Water Amount (\%) & 28.3 \\
& Setting Start Time (min) & 180 \\
& Setting Ending Time (min) & 270 \\
\hline Mechanical & Volume Expansion (mm) & 1 \\
Properties & Compressive Strength - Day 2 (MPa) & 23.1 \\
\hline
\end{tabular}


Table 2. Chemical properties of portland cement

\begin{tabular}{ccc}
\hline & Chemical Composition (\%) & CEM I 42.5 R \\
\hline & $\mathrm{SiO}_{2}$ & 19.67 \\
$\mathrm{Al}_{2} \mathrm{O}_{3}$ & 5.21 \\
$\mathrm{Fe}_{2} \mathrm{O}_{3}$ & 2.68 \\
$\mathrm{CaO}$ & 63.72 \\
$\mathrm{MgO}$ & 3.01 \\
$\mathrm{Na}_{2} \mathrm{O}$ & 0.92 \\
$\mathrm{~K}_{2} \mathrm{O}$ & 0.46 \\
$\mathrm{SO}_{3}$ & 2.13 \\
$\mathrm{MnO}^{\text {Chemical Properties }}$ & --- \\
& $\mathrm{S}$ & -- \\
& $\mathrm{Cl}$ & 0.006 \\
& Loss of ignition & 3.54 \\
& Insoluble residue & 0.5 \\
& Free CaO & 1.85 \\
\hline
\end{tabular}

Topcu and Karakurt [40] were investigated the properties of rebar within increasing temperatures. Samples were exposed to different temperatures for 3 hours and the pull-out test was examined. 2 types of steel were tested which S220 and S420. All mechanical properties were reduced due to the temperature increase of the steel rebars (Fig. 10).

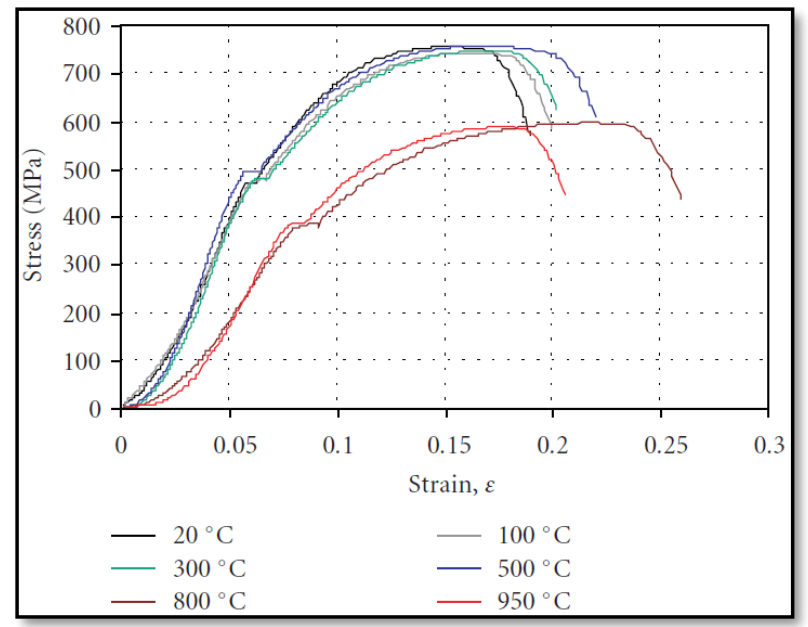

Fig. 10 Stress-strain curve of S420-ribbed steel rebar [40]

Three types of chemical additives were used in our study: set accelerator, set retarder and superplasticizer. In addition, two different corrosion inhibitors were used, namely commercial (calcium nitrite) inhibitor and boron (ecological-green) inhibitor. The additives represented by the series in this study are as follows; CTRL control sample, BORIN boron inhibitor, FERRO calcium nitrite inhibitor, SAK superplasticizer chemical additive, PHIZ setting accelerator chemical additive, and PGEC represents set retarding chemical additive. 


\subsection{Methods}

\subsubsection{Rapid Chloride Permeability Test}

The rapid chloride permeability test was applied in accordance with ASTM C 1202 [41] standard. The experiment is carried out on discs obtained by cutting $100 \times 200 \mathrm{~mm}$ unreinforced cylinder samples with the help of a concrete cutter. The purpose of this experiment is to see to extent of concrete conducts electricity and to determine the electrical resistance of samples that chlorine ions passing through. The rapid chloride permeability test is shown in Figure 11.

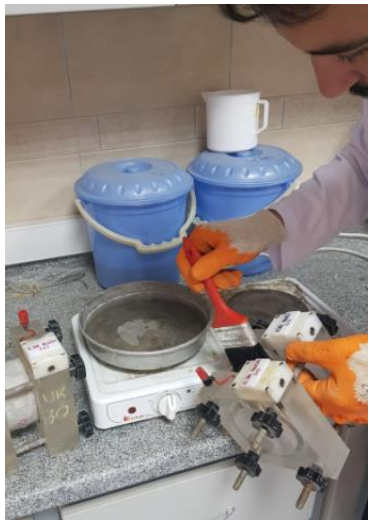

(a)

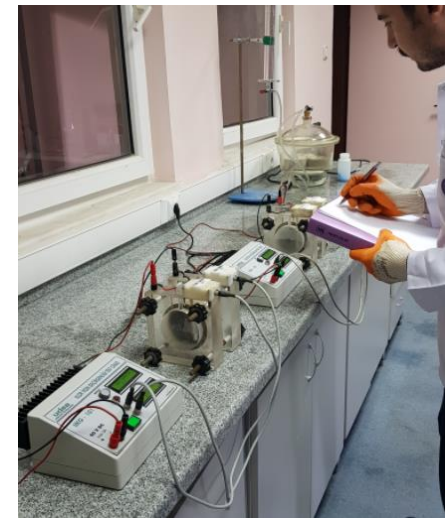

(b)

Fig 11 Preparation of samples (a), Rapid chloride permeability experiment (b)

Information about the chlorine permeability of concrete is obtained according to the total coulomb values obtained as a result of the experiment. The test samples were kept under curing conditions and the rapid chloride permeability test was carried out on the 28th and 90th day. Tests were carried out on three samples for each mixture kept at the specified curing conditions.

\subsubsection{Salt Test}

The rebars were cut into $150 \mathrm{~mm}$ pieces and sent to the laboratory (in airtight bags) for salt testing without being exposed to any chemical effects on their surfaces (to ensure that the test results are not affected). The solution that used for the salt spray test is consists of $5 \%$ of $\mathrm{NaCI}$ (more than seawater, which is between 1.8\% to a max of 3\%) and the $\mathrm{pH}$ of the solution ranges from 6.5 to 7.2. The exposure zone of the salt test spray chamber is maintained at $35^{\circ} \mathrm{C}$. Salt test applied to rebar samples for 1000 hours according to ASTM D4940 [42] standard. The test is continuous for the duration of the entire test period. Salt test results shown in Figure 12. 


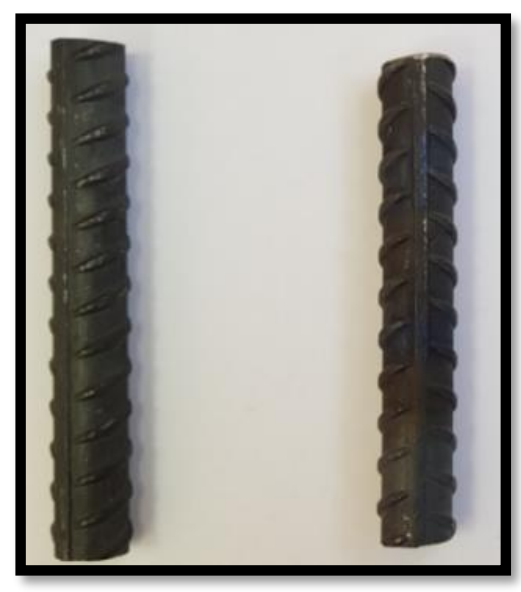

(a)

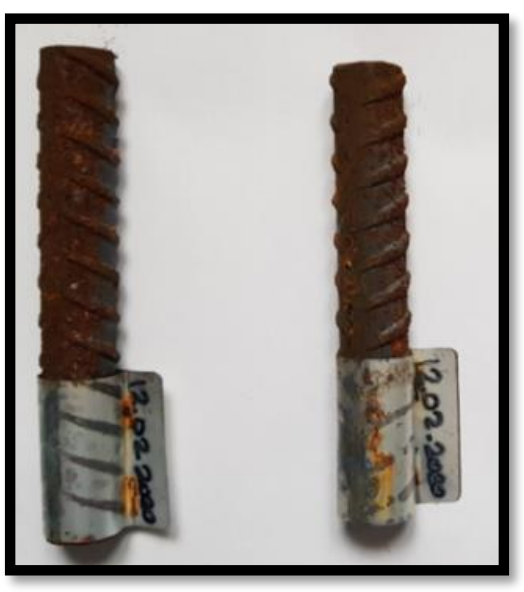

(b)

Fig. 12 Structural rebar before salt test (a), after salt test (b)

\subsubsection{Electrical Resistivity}

This test was carried out on concrete with sample sizes of $100 \times 200$ cylinders. Before starting the experiment, two holes were drilled on the cylinders with $50 \mathrm{~mm}$ between them and the depth of these holes is $10 \mathrm{~mm}$. The probes of the device were placed in these holes. Before this process, the holes were filled with gel according to ASTM C1876 [43] standard.

An important point to be considered while making these measurements is that the samples must be saturated with water. The surfaces of the samples saturated with water waited until they were dry, and the electrical resistance reading was made with the device after that and an idea about the corrosion status of the produced samples was obtained. The test samples were kept under curing conditions and the electrical resistivity test was carried out on the $28^{\text {th }}$ and $90^{\text {th }}$ day. Tests were carried out on three samples for each mixture kept at the specified curing conditions.

\subsubsection{Half-Cell Potential}

The half-cell potential test method, which is based on the principle of instantaneous measurement of the corrosion potential, gives information about the possibility of corrosion in the reinforcement. Half-cell potential is one of the simplest electrochemical measurement methods and can be used in the field, on the structure, or in the laboratory. The potential of the reinforcement in the concrete is determined by establishing the connection of a certain half-cell with the reinforcement. In accordance with ASTM C 876-15 [44] standard, an electrode with a sponge under it is placed on the equipped sample, which is very wet. While the positive pole of the voltmeter is connected to the reinforcement, the cable coming out of the other end of the electrode is connected to the negative pole of the voltmeter. Thus, the circuit is completed and the potential of the reinforcement is measured. As in ASTM C 876-15 standard, copper / copper sulphate (CSE) is used as reference electrode in this study (Fig. 13). 


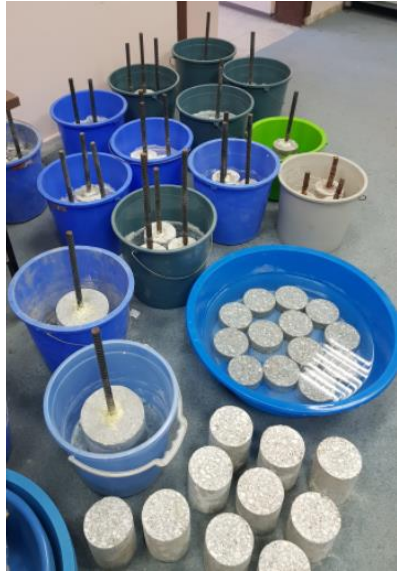

(a)

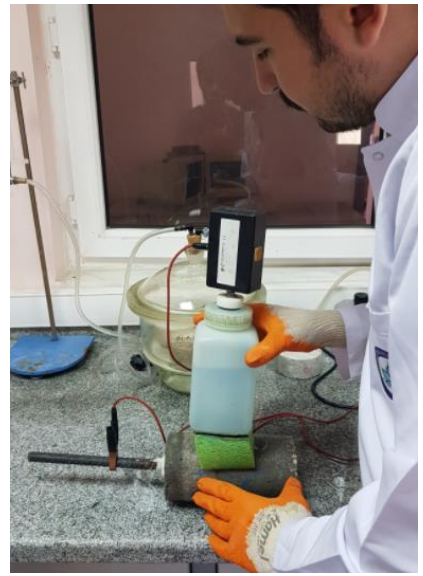

(b)

Fig. 13 Curing the test samples (a), Half-cell potential test (b)

Alhozaimy et al. [45], performed laboratory experiments to evaluate half-cell potential, corrosion current, and concrete resistivity over chloride contaminated concrete specimens, to investigate the phenomenon of high corrosion at intersection of steel rebars in the wall footing. They observed that experimental measurements are higher at intersection of steel bars in comparison with the areas between them. Because of the electrical connectivity and poor concrete microstructures, a high corrosion rate is found after the experimental test.

Duong et al. [46], performed half-cell potential and corrosion current density test on concrete specimens to monitor corrosion activity. Corrosion initiation of rebar and carbonation process was observed with different techniques. They observed that with the increase in leaching exposure carbonation depth also increases. It was seen that, fly ash was not only increasing the corrosion resistance but also carbonation and leaching.

\section{Results and Discussion}

Bare rebars were exposed to a salt test to see the corrosion influence on the surface. After the 1000 hours of salt test, we can easily visually analyze the samples. The experimental results show us that, without an alkaline environment created by concrete, rebars are easily getting corroded. Inhibitors used in concrete form a passive film layer around the reinforcement and this layer protects the reinforcement from corrosion. The alkaline environment of the concrete ensures that this film has a more stable structure. Without these two important factors, the reinforcement loses its strength by being corroded very quickly under the influence of chlorine and water.

An impermeable concrete containing inhibitor will last for many years without corrosion, even if exposed to intense chlorine and water effect. Good quality concrete will prevent the corrosive effect from going deeper and protect the steel from the destructive impact of corrosion (especially in the coast region).

Ecological boron inhibitor and calcium nitrite inhibitor were carried out on 100x200 mm samples, respectively, BORIN and FERRO. As seen in Figure 14, according to the half-cell potential of samples, the corrosion amount decreased in both inhibitors compared to the control sample. This is because, due to the nature of the inhibitors, a passive film was formed 
around the reinforcement by progressing in the concrete and this layer protected the reinforcement against corrosion.

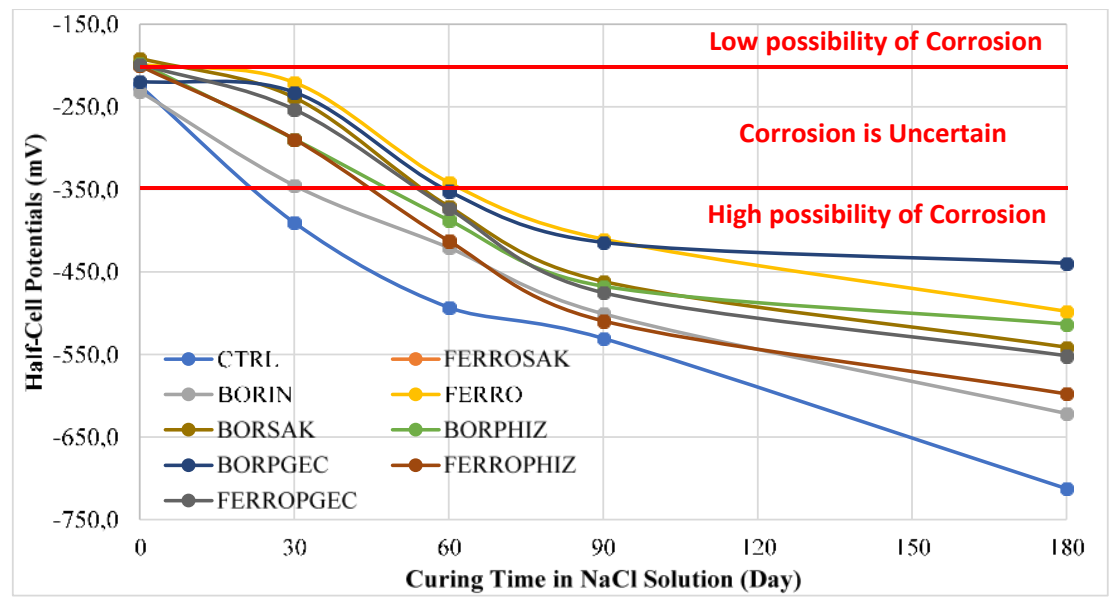

Fig. 14 Half-cell potential results of concrete samples

When we compared the inhibitors among themselves, it was seen that the new generation boron inhibitor slightly reduced the corrosion rate compared to the calcium nitrite inhibitor. This effect increased a little more as time progressed. At the end of 6 months, the boron inhibitor reduced corrosion by $30.1 \%$ compared to the control sample, while the calcium nitrite inhibitor reduced it by $14.6 \%$. When we look at the half-cell potential test results, we see that all test samples are corroded. This is because the test chambers used in the experiment contain a high percentage of $\mathrm{NaCl}$.

In such a high chloride environment (this value was chosen to be similar to seawater salt concentration), It is quite natural to start corrosion in samples in a short time. The important thing is, which test sample corroded less as a result of the comparison. After the experiment, the best results were given by an ecological and non-toxic boron corrosion inhibitor among all chemical additive and inhibitor series during the same curing time. Boron corrosion inhibitor gave better results compared to other samples thanks to the natural borane complex it contains.

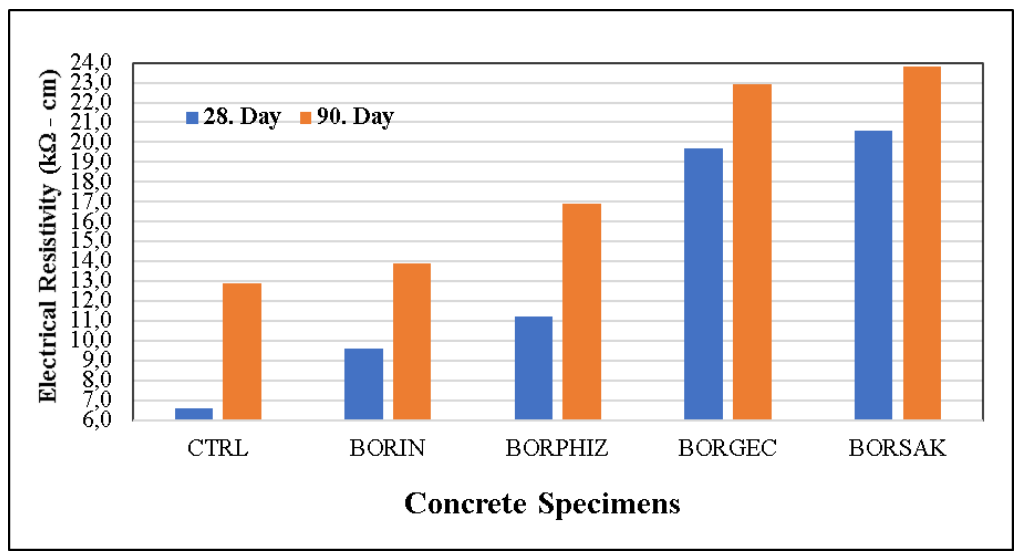

Fig. 15 Electrical resistivity of specimens with boron inhibitor 
In the Figure 15, the change of electrical resistance results of concrete with boron inhibitor and chemical additives over time is shown. The combination of boron inhibitors and chemical additives has improved concrete properties. In concrete samples in which set retarder and boron inhibitor were used together, electrical resistance value increased by $19 \%$ compared to control samples. In addition, BORSAK series obtained the highest value of these series, 23.8, which is $85 \%$ higher than the control series.

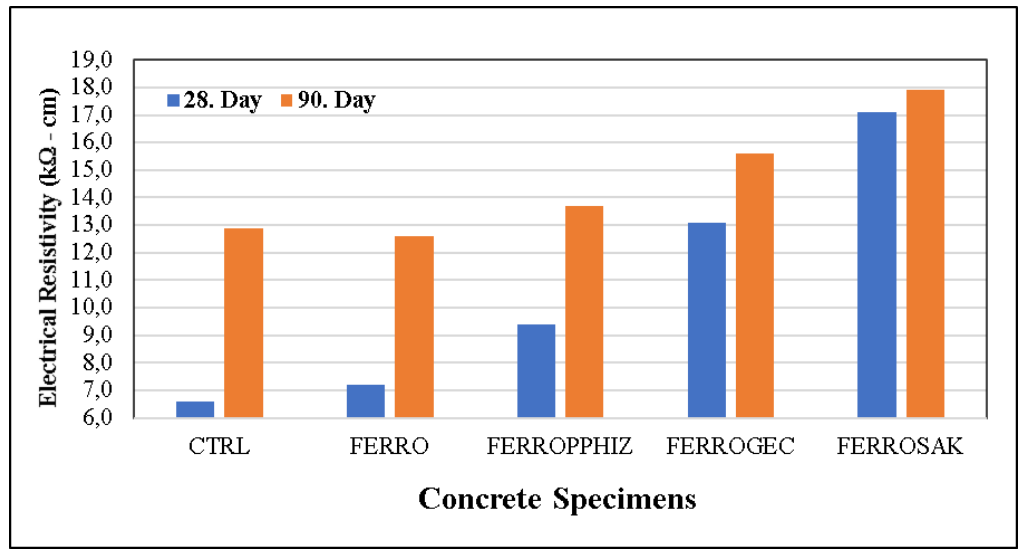

Fig. 16 Electrical resistivity of specimens with calcium nitrate inhibitor

In the Figure 16, the change of electrical resistance results of concretes with calcium nitrite inhibitor and chemical additives over time is shown. When calcium nitrite is used together with other chemical additives in reinforced concrete, it did not damage the internal structure of the cement. It is known as a result of experimental studies that calcium nitrite inhibitor increases the electrical conductivity of concrete due to its nature. However, with the use of other chemical additives, the concrete reached a better consistency, settled in the mold better and the impermeability increased. Electrical resistance values increased with the increase of impermeability.

It is understood from the electrical resistance test results that even if the ecological boron inhibitor was used together with chemical additives, it gave a more positive result (high electrical resistance) than the calcium nitrite inhibitor (harmful and carcinogenic).

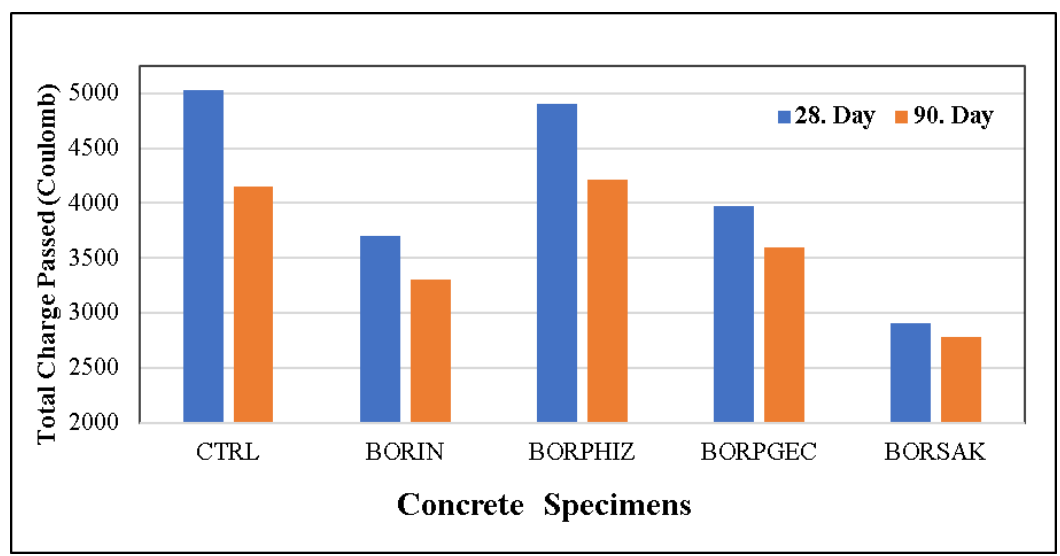

Fig. 17 Rapid chloride permeability of specimens with boron inhibitor 
The low electrical resistance value indicates that concrete has a more permeable structure. Therefore, in terms of resistance to corrosion, higher electrical resistance value is desired. However, rapid chloride permeability results are inversely proportional to the results here. High rapid chlorine permeability values indicate that concrete samples are more permeable and will corrode more easily. In other words, lower permeability values are preferred in terms of corrosion resistance.

Values related to chloride ion permeability in concretes containing inhibitors are given above (Fig. 17). The boron inhibitor reduced the chloride permeability of concrete by $45 \%$ compared to the control sample. The combined use of boron inhibitor and superplasticizer additive enabled the concrete to settle into the mold better and reduced the permeability. Set accelerator and set retarding additives contain a little chlorine. Therefore, the fast chloride permeability value of the concrete samples where these additives were used was higher. In general, the permeability values of all concrete series using boron inhibitors were lower than the control sample. The longer the curing time, the better the chemical reactions in the cement and the decrease in the chlorine permeability values. The lowest chlorine ion permeability value in these concrete samples belongs to the boron and superplasticizer series with 2779 Coulomb.

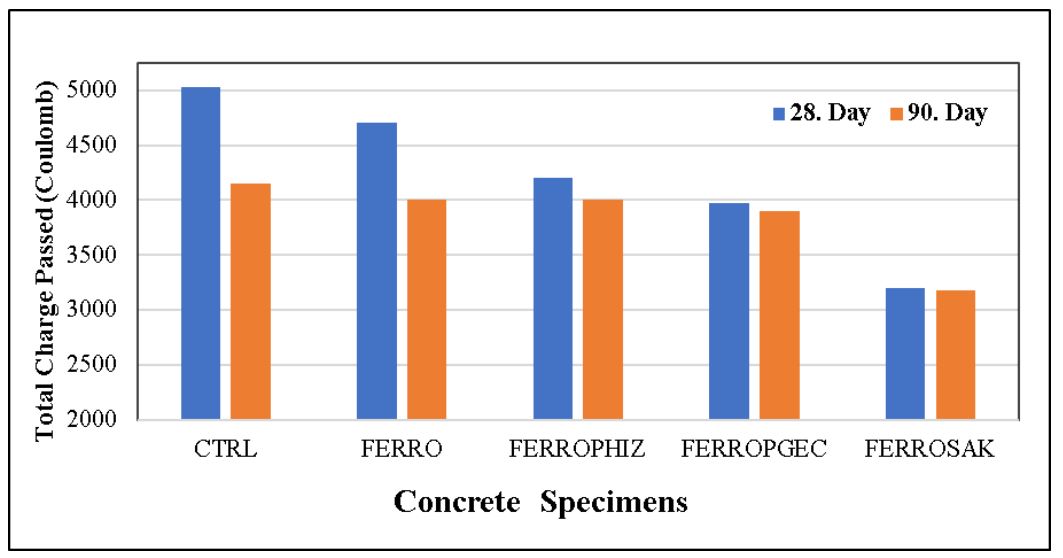

Fig. 18 Rapid chloride permeability of specimens with calcium nitrate inhibitor

When calcium nitrite inhibitor was used alone in the concrete mixture, it slightly affected the chlorine permeability value of the concrete compared to the control sample (Fig. 18). Since calcium nitrite increases the electrical conductivity of concrete, rapid chloride permeability values are not as low as in boron inhibitors. But there is a general decrease in permeability. In particular, the combined use of calcium nitrite and superplasticizers significantly reduced the permeability of concrete by about $38 \%$. The rapid chloride permeability value for this series was determined as 3179 Coulomb.

\section{Conclusions}

The corrosion phenomenon is consisting of so many complex reactions and researchers are keep increasing their study on this field. However, from the case histories of several corrosioneffected structures, it is found that in the majority of cases the corrosion is mainly due to nonobservance of specified construction and concreting practice. Therefore, it is necessary to continuing training of the workers on-the-job so that they observe good concreting practice.

Corrosion activity in reinforced-concrete structures primarily depends upon the activation period which is influenced by the interaction of the tensile strength and thickness of the 
concrete cover and the penetration of moisture, oxygen, chlorides and toxic components of sulfates, phosphates and nitrates.

Corroded structural members with cracking and spalling of the concrete cover can be repaired by jacketing. Corrosion damage in members with internal cracks and exterior micro-cracks is not visible to the naked eye. The cost of repairs to structures damaged by corrosion is many times more than the additional cost involved in extra care and corrosion-preventive methods adopted in selecting the standard constituent materials, and compacting and curing the concrete. The following preventive measures can be adopted to mitigate corrosion damage in reinforced-concrete structures:

- Use of pozzolana cement blended with $20 \%$ of pozzolana materials or ordinary Portland cement,

- Thorough washing of aggregates to eliminate chlorides and other corrosive salts,

- Mixing the concrete with potable water having a pH value not less than 6,

- Designing a low-slump concrete with minimum cement content of $350 \mathrm{~kg} / \mathrm{m}^{3}$ and the maximum water-cement ratio of 0.50 ,

- Superplasticizers might be used in order to obtain a low water-cement ratio, this will increase the resistivity against corrosion,

- Use of organic and inorganic inhibitors to decrease the corrosion risk,

- Thoroughly compaction of concrete in the molds,

- Curing with water having a $\mathrm{pH}$ value not less than 6 for at least seven days until the concrete attains $70 \%$ of its design strength and prevent plastic shrinkage cracks,

- Thickness of concrete cover should be smooth and sufficient.

For important structures in an aggressive environment, the concrete cover may be protected with surface-applied inhibitors or coatings with proper thickness.

In this study, the effect of different inhibitors and chemical additives on the corrosion of reinforced concrete steel was investigated. As a result of experimental studies, it was concluded that the ecological boron inhibitor did not damage the structure of the reinforcement in the concrete and could be used instead of the calcium nitrite inhibitor produced in the market. The electrical resistance, rapid chloride permeability and half-cell potential experiments show that samples containing boron inhibitors gave the best results compared to other samples.

As a result of the experimental studies, the half-cell potential values of the samples containing boron inhibitors were found to be $30.1 \%$ less. This result is much better than a calcium nitrite inhibitor. The control sample without any chemical additives was the most corroded sample. The best result was obtained from the sample named BORPGEC with boron and set retarder.

When we look at the electrical resistance test results, we see that the electrical resistance of concrete increases with the use of chemical additives. Here, boron and super plasticizer series (BORSAK) gave the best results. Electrical resistance of this series is $85 \%$ higher than the control sample. It is known as a result of experimental studies that calcium nitrite inhibitor increases the electrical conductivity of concrete due to its nature. However, with the use of other chemical additives, the concrete reached a better consistency, settled in the mold better and the impermeability increased. Electrical resistance values increased with the increase of impermeability.

In the rapid chlorine permeability test, the series with boron and super plasticizer gave the best result, reducing the chlorine permeability of concrete by $45 \%$. These results are also parallel in calcium nitrite series, but not as good as boron inhibitor. The best result for samples containing calcium nitrite was obtained from the series with calcium nitrite and super plasticizer (FERROSAK), and this series reduced the permeability of concrete by $38 \%$ compared to the 
control series. The combined use of boron inhibitor and superplasticizer additive enabled the concrete to settle into the mold better and reduced the permeability. Set accelerator and set retarding additives contain a little chlorine that is why this series are a bit higher permeability values than other series.

The boron inhibitor, which will be mass-produced in the future, will provide a significant national income to the country's economy. The boron element has been used by researchers in many fields, and as these researches increase, more efficient properties of the element will emerge.

\section{References}

[1] Topcu IB, Unal 0, Uygunoglu T. Chloride effect in reinforced concrete structures, TCCE İzmir Branch, Concrete Corner, 2005; 124: 36 - 41.

[2] Topcu IB, Boga AR. Investigation of reinforcement corrosion in fly ash concretes with accelerated method, 3rd National Building Material Congress and Exhibition, 15-17 November 2006, İstanbul.

[3] Shalabi K, Nazeer AA. Ethoxylates nonionic surfactants as promising environmentally safe inhibitors for corrosion protection of reinforcing steel in $3.5 \% \mathrm{NaCl}$ saturated with $\mathrm{Ca}(\mathrm{OH}) 2$ solution. Journal of Molecular Structure, 2019; 1195: 863 - 876. https://doi.org/10.1016/i.molstruc.2019.06.033

[4] Quraishi MA, Nayak DK, Kumar R, Kumar V. Corrosion of Reinforced Steel in Concrete and Its Control: An overview. Journal of Steel Structures and Construction, 2017; 3(1): 1-6. https://doi.org/10.4172/2472-0437.1000124

[5] Basic corrosion cell. Received from; 'http://korkappvccoatedconduit.blogspot.com/2014 /04/explanation-of-basic-corrosion-cell.html'

[6] Electrochemical reaction on rebar. Received from; 'https://www.cement.org/learn /concrete-technology/durability/corrosion-of-embedded-materials'

[7] Yang H, Li W, Liu X, Liu A, Hang P, Ding R, Li T, Zhang Y, Wang W, Xiong C. Preparation of corrosion inhibitor loaded zeolites and corrosion resistance of carbon steel in simulated concrete pore solution. Construction and Building Material, 2019; 225: 90 - 98. https://doi.org/10.1016/j.conbuildmat.2019.07.141

[8] Anitha R, Chitra S, Hemapriya V, Chung IM, Kim SH, Prabakaran M. Implications of ecoaddition inhibitor to mitigate corrosion in reinforced steel embedded in concrete. Construction and Building Material, 2019; 213: 246 - 256. https://doi.org/10.1016/j.conbuildmat.2019.04.046

[9] Hossain SMZ, Kareem SA, Al-Shater A, Ezuber H, Hossain MM, Razzak SA. Effects of cinnamaldehyde as an eco-friendly corrosion inhibitor on mild steel in aerated $\mathrm{NaCl}$ solutions. Arabian Journal for Science and Engineering, 2020; 45: 229 - 239. https://doi.org/10.1007/s13369-019-04236-4

[10] Lee HS, Ryu HS, Park WJ, Ismail MA. Comparative study on corrosion protection of reinforcing steel by using amino alcohol and lithium nitrite inhibitors. Materials (Basel), 2015; 8: 251 - 269. https://doi.org/10.3390/ma8010251

[11] Deng M, Zhang Y, Li Q. Shear strengthening of RC short columns with ECC jacket: Cyclic behavior tests. Engineering Structures, 2018; 160:535-545. https://doi.org/10.1016/j.engstruct.2018.01.061

[12] Di Carlo F, Meda A. Numerical cyclic behaviour of un-corroded and corroded RC columns reinforced with HPFRC jacket. Composite Structure, 2017; 163:432 - 443. https://doi.org/10.1016/i.compstruct.2016.12.038

[13] Meda A, Mostosi S, Rinaldi Z, Riva P. Corroded RC columns repair and strengthening with high performance fiber reinforced concrete jacket. Materials and Structures, 2016; 49(5):1967-1978. https://doi.org/10.1617/s11527-015-0627-1 
[14] Zhang D, Ghouleh Z, Shao Y. Review on carbonation curing of cement-based materials. Journal of CO2 Utilization, 2017; 21: 119 - 131. https://doi.org/10.1016/j.jcou.2017.07.003

[15] Song N, Wang Z, Liu Z, Zhou J, Zheng D. Study on improvement of durability for reinforced concrete by surface-painting migrating corrosion inhibitor and engineering application. In: 1st International Conference on New Material and Chemical Industry (NMCI2016). IOP Conference Series: Materials Science and Engineering, 2017. p. 167. https://doi.org/10.1088/1757-899X/167/1/012072

[16] Damages caused by reinforcement corrosion in columns and beams. Received from; 'https://theconstructor.org/structural-engg/methods-of-concrete-column-repair/5833/

[17] Ryu HS, Singh JK, Lee H, Ismail MA, Park W. Effect of LiNO2 inhibitor on corrosion characteristics of steel rebar in saturated $\mathrm{Ca}(\mathrm{OH}) 2$ solution containing $\mathrm{NaCl}$ : An electrochemical study. Construction and Building Materials, 2017; 133(15): 387 - 396. https://doi.org/10.1016/i.conbuildmat.2016.12.086

[18] Shan H, Xu J, Wanga Z, Jiang L, Xu N. Electrochemical chloride removal in reinforced concrete structures: Improvement of effectiveness by simultaneous migration of silicate ion. Construction and Building Materials, 2016; 127: $344 \quad-\quad 352$. https://doi.org/10.1016/j.conbuildmat.2016.09.137

[19] Pathak RK, Mishra P. Drugs as corrosion inhibitors: A review. International Journal of Science and Research, 2016; 5: 671 - 677. https://doi.org/10.21275/v5i4.NOV162623

[20] Shi Z, Lothenbach B, Geiker MR, Kaufmann J, Leemann AS, Ferreiro S, Skibsteda J. Experimental studies and thermodynamic modeling of the carbonation of Portland cement, metakaolin and limestone mortars. Cement and Concrete Rsrch., 2016; 88: 60-72. https://doi.org/10.1016/j.cemconres.2016.06.006

[21] Epoxy coated and galvanized reinforcements. Received from; 'https://www.harrissupply solutions.com/epoxy-coated-rebar.html'

[22] Bouazaoui L, Li A. Analysis of steel/concrete interfacial shear stress by means of pull out test. International Journal of Adhesion \& Adhesives 28. Elsevier. 2008. pp. 101-108. https://doi.org/10.1016/i.ijadhadh.2007.02.006

[23] Ryu HS, Singh JK, Yang HM, Ismail MA. Evaluation of corrosion resistance properties of N, $\mathrm{NO}$-dimethyl ethanolamine corrosion inhibitor in saturated $\mathrm{Ca}(\mathrm{OH}) 2$ solution with different concentrations of chloride ions by electrochemical experiments. Construction and Building Materials, 2016; 114: 223 - 231. https://doi.org/10.1016/i.conbuildmat.2016.03.174

[24] Elsener B, Angst U. Corrosion inhibitors for reinforced concrete. Science and Technology of Concrete Book, 2016. https://doi.org/10.1016/B978-0-08-100693-1.00014-X

[25] Insufficient implementation of vibration on concrete pouring. Received from; 'https://ww w.youtube.com/watch?v=SdDEzuYFPcE\&ab_channel=CivilSitevisit'

[26] Kaur K, Goyal S, Bhattacharjee B, Kumar M. Efficiency of migratory-type organic corrosion inhibitors in carbonated environment. Journal of Advanced Concrete Technology, 2016; 14: 548 - 558. https://doi.org/10.3151/jact.14.548

[27] Inadequate use of concrete cover. Received from; 'https://civildigital.com/effectscorrosion-reinforcement-signs-preventive-measures/'

[28] Elfmarkova V, Spiesz P, Brouwers HJH. Determination of the chloride diffusion coefficient in blended cement mortars. Cement and Concrete Research, 2015; 78: 190 -199. https://doi.org/10.1016/j.cemconres.2015.06.014

[29] Habib A, Yildirim U, Eren O. Column repair and strengthening using RC jacketing: a brief State of the art review. Innovative Infrastructure Solutions, 2020; 5: 1 - 11. https://doi.org/10.1007/s41062-020-00329-4

[30] Raja PB, Ghoreishiamiri S, Ismail M. Natural corrosion inhibitors for steel reinforcement in concrete - A review. World Scientific Publishing Company, 2015; 22: 68 - 75. https://doi.org/10.1142/S0218625X15500407

[31] Diamanti MV, Pérez Rosales EA, Raffaini G, Ganazzoli F, Brenna A, Pedeferri M, Ormellese M. Molecular modelling and electrochemical evaluation of organic inhibitors in concrete. Corrosion Science, 2015; 100: 231 - 241. https://doi.org/10.1016/i.corsci.2015.07.034 
[32] Larouj M, Lgaza AH, Serrard H, Zarroka H, Bourazmib H, Zarroukc A, Elmidaouia A, Guenbourb A, Boukhrisd S, Ouddaa H. Adsorption properties and inhibition of carbon steel corrosion in hydrochloric acid solution by ethyl 3-hydroxy-8-methyl-4-oxo-6-phenyl-2-(ptoly)-4,6- dihydropyrimido[2,1-b] [1,3]thiazine-7-carboxylate. Journal of Materials and Environmental Science, 2015; 6(11): 3251 - 3267.

[33] Gerengi H, Bilgic H, Sahin HI. Corrosion effect of ecologic inhibitors such as nut shell, pomegranate and savoy cabbage on zinc plate in $5 \% \mathrm{NaCl}$ environment. Düzce University Journal of Forestry, 2011; 6: 10 - 23.

[34] Gerengi H, Ugras HI, Yildiz M. Using of ionic liquids containing boron cation as corrosion inhibitor in 0.1 M HCI environment. Journal of Advanced Technology Sciences, 2017; 6(1): $11-22$.

[35] Abdulrahman AS, Ismail M, Hussain MS. Corrosion inhibitors for steel reinforcement in concrete: A review. Scientific Research and Essays, 2011; 6: 4152-4162. https://doi.org/10.5897/SRE11.1051

[36] Ryu HS, Singh JK, Lee H, Park W. An electrochemical study to evaluate the effect of calcium nitrite inhibitor to mitigate the corrosion of reinforcement in sodium chloride contaminated $\mathrm{Ca}(\mathrm{OH}) 2$ solution. Advances in Materials Science and Engineering, 2017. https://doi.org/10.1155/2017/6265184

[37] Okeniyi OJ, Omotosho OA, Ogunlana 00, Okeniyi ET, Owoeye TF, Ogbiye AS, Ogunlana EO. Investigating prospects of Phyllanthus muellerianus as ecofriendly/sustainable material for reducing concrete steel reinforcement corrosion in industrial/microbial environment. Energy Procedia, 2015; 74: 1274-1281. https://doi.org/10.1016/i.egypro.2015.07.772

[38] TS EN 197-1, Cement- Part 1: Compositions and conformity criteria for common cements. Turkish Standards, Ankara, 2012.

[39] TS 708, Steel for the reinforcement of concrete - Reinforcing steel. Turkish Standards, Ankara, 2016.

[40] Topcu IB, Karakurt C. Properties of Reinforced Concrete Steel Rebars Exposed to High Temperature. Research Letters in Materials Science, 2008; Vol. 2008, 1-4. https://doi.org/10.1155/2008/814137

[41] ASTM C1202. Standard Test Method for Electrical Indication of Concrete's Ability to Resist Chloride Ion Penetration. ASTM International. 2019.

[42] ASTM D4940. Standard Test Method for Conductimetric Analysis of Water-Soluble Ionic Contamination of Blast Cleaning Abrasives. ASTM International. 2020.

[43] ASTM C 1876. Standard Test Method for Bulk Electrical Resistivity or Bulk Conductivity of Concrete. ASTM International. 2019.

[44] ASTM C 876 - 15. Standard Test Method for Corrosion Potentials of Uncoated Reinforcing Steel in Concrete. ASTM International. 2015.

[45] Alhozaimy A, Hussain RR, Al-Zaid R, Negheimish AA. Investigation of severe corrosion observed at intersection points of steel rebar mesh in reinforced concrete construction. Construction and Building Materials. 2012; vol. 37, pp. 67-81. https://doi.org/10.1016/j.conbuildmat.2012.07.011

[46] Duong VB, Sahamitmongkol R, Tangtermsirikul S. Effect of leaching on carbonation resistance and steel corrosion of cement-based materials. Construction and Building Materials. 2013; vol. 40, pp. 1066-1075. https://doi.org/10.1016/j.conbuildmat.2012.11.042 